\title{
随意動作に伴う脳運動関連電位
}

一特に運動電位，運動後陽性電位についての考察一

$\begin{array}{llll}\text { 西 } & \text { 平 } & \text { 賀 } & \text { 昭(筑波大学体育科学系) } \\ \text { 荒 } \text { 木 } & \text { 秀 } \text { 夫(筑波大学体育科学系) } \\ \text { 藤 田 } & \text { 紀 } & \text { 盛 (筑波大学体育科学系) } \\ \text { (昭和54年10月 29日 受付) }\end{array}$

\section{Movement-Associated Cortical Potential Accompanying Voluntary Movement with Special Reference to Motor Potential and Positive Potentials after Movement-}

\author{
Yoshiaki Nishihira ${ }^{1}$ \\ Hideo Araki ${ }^{1}$ \\ Tatsumori Fujita ${ }^{1}$
}

\begin{abstract}
The study of movement-associated cortical potential was first reported by H.H. Kornhuber and L. Deeke in 1965. The reports as to $\mathrm{N}_{1}$ potential (readiness potential) of movement-associated cortical potentials beginning $800 \mathrm{msec}-1500 \mathrm{msec}$ in advance of voluntary movement were presented by many investigators, and agreement was reached on some of the points. However, some of the points still remained disagreed. Therefore, the present authors had investigated the relation of $N_{1}$ potential with motor control and the difference between $N_{1}$ potential and CNV, up to the present, and presented some of the findings. Then, the authors have attempted at elucidating the significance of $\mathrm{N}_{2}$ potential (motor potential) beginning 91-187msec in advance of voluntary movement, $\mathrm{P}_{2}$ potential (the first positive potential after movement) beginning about $160 \mathrm{msec}$ after voluntary movement, and $\mathrm{P}_{3}$ potential (the second positive potential after movement) beginning about $263 \mathrm{msec}$ after voluntary movement which are constituting the movement-associated cortical potentials, and a few findings have been presented in the previous report. However, data that supported their findings remain inadeqate, up to the present.

The present study, therefore, was intented to investigate, in more detail, the relations of $\mathrm{N}_{2}$ potential, $\mathrm{P}_{2}$ potential, and $\mathrm{P}_{3}$ potential to the motor control, with the method of simultaneous measurement of movement-associated cortex potentials, S.S.C.P (somatic, stimulus,cortex, potential) and cortex potential accompanying passive movement. Such method has been applied to the human subjects in very limited ocassions.
\end{abstract}

The following results were obtained:

1 The University of Tsukuba, Institute of Health and Sport Science, Niiharigun Ibaraki (305) 
1) The distribution over the scalp of $N_{2}$ potential showed maximum at $C_{3}$ in case of voluntary right upper arm flexion movement. The maximum was at $\mathrm{C}_{4}$ in case of voluntary left upper arm flexion movement.

2) The distribution over the scalp of $\mathrm{P}_{2}$ potential showed maximum at $\mathrm{Cz}$ in case of voluntary right upper arm flexion movement. The maximum was also at $\mathrm{C}_{z}$ in case of voluntary left upper arm flexion movement.

3) $P_{3}$ potential and positive potential of passive flexion movement appeared both semispheres over central area. However, the difference of the amplitude of the these potentials was not significant.

4) The appearance latency of $P_{3}$ potential and of positive potential appearing after passive flexion movement showed quite similar value. When the amplitude of these potentials was compared, $\mathrm{P}_{3}$ potential showed higher tendency than the positive potential after passive flexion movement.

From the results described above, the authors may conclude that (1) $\mathrm{N}_{2}$ potential reflects expression of nerve excitation, namely, activity of corticalspinal tract concerning efferent discharges of pyramidal tract, (2) $\mathrm{P}_{2}$ potential dose not reflect peripheral feedback, but suggests the possibility of reflecting central feedback, and (3) $P_{3}$ potential reflects peripheral feedback from muscle, joint, and others. These findings are in support of the previous results reported by other investigators.

(Yoshiaki Nishihira, Hideo Araki, and Tatsumori Fujita, "Movement-associated cortical potential accompanying voluntary movement - with special reference to motor potential and positive potentials after movement-", Jap. J. Phys. Educ., 26-1:43-56, June, 1981)

\section{実 臨目的}

随意動作に伴って，頭皮上に 4 つの電位変化が 出現することは，多くの矵究者の一致する ${ }^{3}$ ，4）， 11),22，24）埌告である。著者らは今まで 4 つの電位 変化の中で，随意䡃作に先行して約 800 1500 $\mathrm{msec}$ に出現する $\mathrm{N}_{1}$ 電位（準備電位）に考察を限 定して，その電位と区応時間との関係，およびN 電位と C.N.V. (随伴性陰性変動) の相違につい て垁験的に検討し，報告24，25)してきた。

その理由としては, 脳運動関連電位に関する今 日までの研究の焦点が， $N_{1}$ 電位と随意動作の準 備状態形成との関連性を実証するという方向に向 けられていて，著者らもその動问を踏䪭したとい うこと。さらにまたもう一つの理由は，感覚刺激 のみに注意を集中させ，何ら動作課題を与えなく ても頭皮上に出現する C.N.V. と呼ばれている現 象と $N_{1}$ 電位がきわ的て類似しているゆえに， そ の両電位の相違を検討しておかなければ， $\mathrm{N}_{1}$ 電 位と随意動作の準備状態形成との関連性の仮説が 成立せず，ひいては，脳運動関連電位を構成する
各電位成分と運動制御との関連性を検討すること 自体不可能になるからである。

ところが近年 (1975)，J. Arezzo and H. G. Vaughan は随意動作に伴って頭皮上から $5 つ の$ 電位変化を導出し，脳運動関連電位を構成する 4 つの電位成分にもう一つの電位成分を付加し，そ れを $\mathrm{P}_{3}$ 電位（運動後第 2 陽性電位）と命名した。

今までも，随意動作に先行して約 $139 \pm 48 \mathrm{msec}$ に出現する $\mathrm{N}_{2}$ 電位 (運動電位)，随意動作後約 160 土24msecに出現する $\mathrm{P}_{2}$ 電位（運動後第 1 陽性電 位)，随意動作後約 $263 \pm 36 \mathrm{msec}$ に出現する $\mathrm{P}_{3}$ 電 位（運動後第 2 陽性電位）に関する報告は若干あ り，いくつかの知見が提示されている。しかしな がら，現在，それらの知見1，2)を根执づけるの に十分なデーターが存在せず，あらゆる角度から のデーターの提示が望まれている現状である。

そこで著拍らは，今までの研究報告 1)，2）,3） 十分に考虑しつつ，本論文においては，随意哩作 に伴う脳電位, 受動動作に伴う脳電位，体性感覚 刺激大脑誘発電位 (Somatic, Stimulus Corter, Potential, 以下S.S.C.P. と略す) の同時澌定とい 
う。ヒトにおいては今まで報告の少ない実験方法 を用いて随意動作に先行して出現する $\mathrm{N}_{2}$ 電位（運 動電位)，随意動作後に出現する $\mathrm{P}_{2}$ 電位（運動後 第 1 陽性電位)， $\mathrm{P}_{3}$ 電位（運動後第 2 陽性電位） と動作制御 1)，2，3）との閏連性に関する今日まで のいくつかの知見を詳細に検討し，根拠づける一 助にするとともに，究極的には運動制御機構の一 端解明の一助にすることを目的とした。

さらに加えて，運動後陽性電位である $\mathrm{P}_{2}, \mathrm{P}_{3}$ 電 位と動作との関連性を検討するために，体性感覚 剌激大脑誘発電位（S.S.C.P.）の中で，正中神経 刺激後䄪 $14 \mathrm{msec}$ に出現する $\mathrm{P}_{1}$ 電位, 約 $20 \mathrm{msec}$ に出現する $\mathrm{N}_{2}$ 電位の頭皮上分布と，既述の $\mathrm{P}_{2}$ 電 位 (運動後第 1 陽性電位), $\mathrm{P}_{3}$ 電位（運動後第 2 陽性電位）のそれを比較検討した。

\section{実 験 方 法}

a 実験条件

被検者は筑波大学の健康な男子学生 5 名であっ た。(年龄19-21歳)。被検者をシールド内のペッ ド上に安静仰臥位状態にし, 開眼させ, 眼 前約
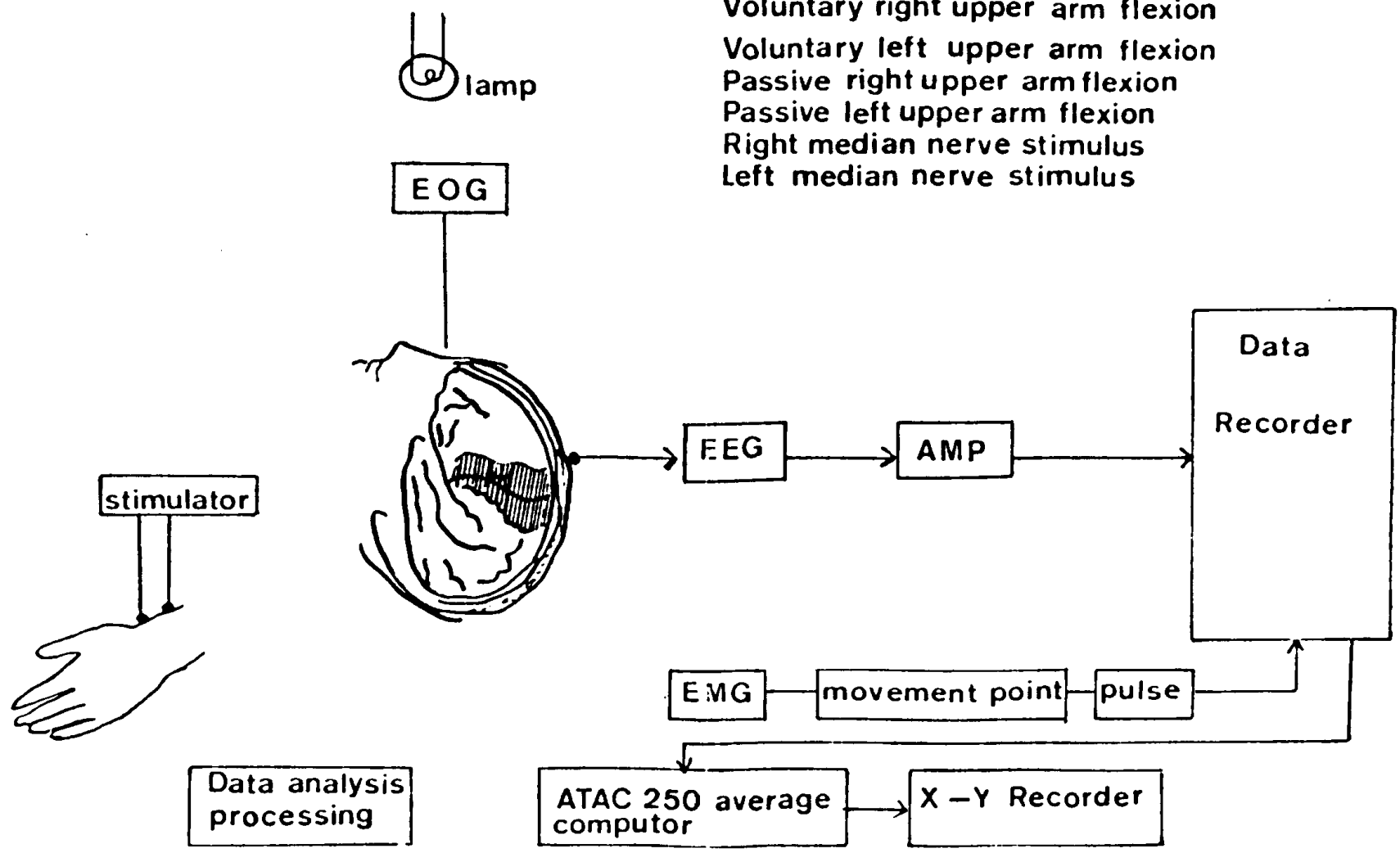

Fig. 1 The experimental arrangement of the present study and data analysis processing.
$1.5 \mathrm{~m}$ に装着した赤ランプを擬視させ，次のよう な動作条件を与えた。

（1）自発的な左，右上腕届曲動作（被検者江时 闺節角度を䄪 90 度に届曲維持させた状態から，自 発的に任意の間隔で上腕を屈曲する)。

（2）受動的な左，右上腕屈曲動作（被検者に， 时関節角度を約 90 度に届曲維持させた状態から， 検者をたは第三者が他動的に任意の間隔で上腕を 風曲させる）

（3）被検者を仰臥位安静状態にし，左右各々の 正中神経に任意の間隔で電気刺激を与えて，頭皮 上から体性感覚刺激大腷誘発電位 (S.S.C.P.) を 導出し，その電位の頭皮上分布を確認した。その 時の刺激電王は，剌激の artifacts のため，脳波 の分析が不可能になるおそれを考虑して母指収縮 闘値とした。被検者には既述の動作条件の下で動 作遂行するように指示した。動作遂行前後にはな るべく眼球運動をしないように注意した。動作肢 以外にはなるべく動かさないようにし，リラック スするよう指示した。

b 揤定方法と導出部位

\section{Movement conditions}

Voluntary right upper arm flexion Voluntary left upper arm flexion Passive right upper arm flexion Passive left upper arm flexion Right median nerve stimulus Left median nerve stimulus 
脑波は頭皮上から表面導出法とし，電極は譄波 用スピン電極を用いた。電極の配置は国際式10一 20電極配置法に従った。脳波の導出は両耳梁を共 通にし，それを基準電極に用いた単極㮍出法とし た。導出部位は $\mathrm{C}_{3}, \mathrm{C}_{2}, \mathrm{C}_{4}, \mathrm{P}_{3}, \mathrm{P}_{4}, \mathrm{Pz}, \mathrm{Fz}$ あった。睬波の湘定とデーターの解析は Fig. 1 のような配列で行なった。

脳波は，脳波計（日本光電製）で増幅，記録し た。脳運動関連電位を測定する時定数は 0.6 秒, 較正電圧は50 $\mu v / \mathrm{cm}$ であった。S.S.C.P. を測定す る時の時定数は 0.3 秒，筋電位を湘定する時の時 定数は0.03秒であった。筋電位の導出電極は直径 $8 \mathrm{~mm}$ の血型電極（銀一塩化銀不分極電極）を用 いた。睬波，筋電位はいったん cassette data recorder (4 channel magnetic tape) に収録し た。

データ一解析過程において，加算機を掃引する ためのトリガーパルスは，脑運動関連電位を測定 する時においては，筋放電と同時に（あるいは勤 作と同時に）パルスが出現するように設定し，ま た S.S.C.P. 測定時においては，正中神経剌激と同
時にパルスが出現するように設定して，そのパル スを用いた。そのトリガーパルスも脳波，箭電位 と一粕に，cassette data recorder に收録した。 実験䅂了後，収録したデーターは，トリガーパ ルスを基淮に逆方向, 順方向に再生させて, ATAC 250 (日本光電製) 上で平均加算し，X-Y recorder に記述した。加算回数は70〜100回で あった。ATAC 上での脳運動闻連電位の解析時 間は 2 秒，S.S.C.P.は50msecであった。ただし， artiffacts のある筒所はすべてデーターから除 外した。なお，脳運動関連電位の典型的な例と測定 基準はFig. 2 に示してある。しかしながら，既述 した脳運動関連電位の中の $\mathrm{P}_{3}$ 電位（運動啳第 2 陽 性電位）は常に明白に確認できるむのではなく，

Fig. 3 に示したように, 確認不可能な場合もあ る。S.S.C.P. の典型的な例と揤定基準はFig. 4 に 示してある。さらにFig. 5 は，随意動作に伴う脳 運動関連電位と受動動作に伴って頭皮上に出現す る脎電位の相違と, 後者の腷電位の揤定基準を示 してある。
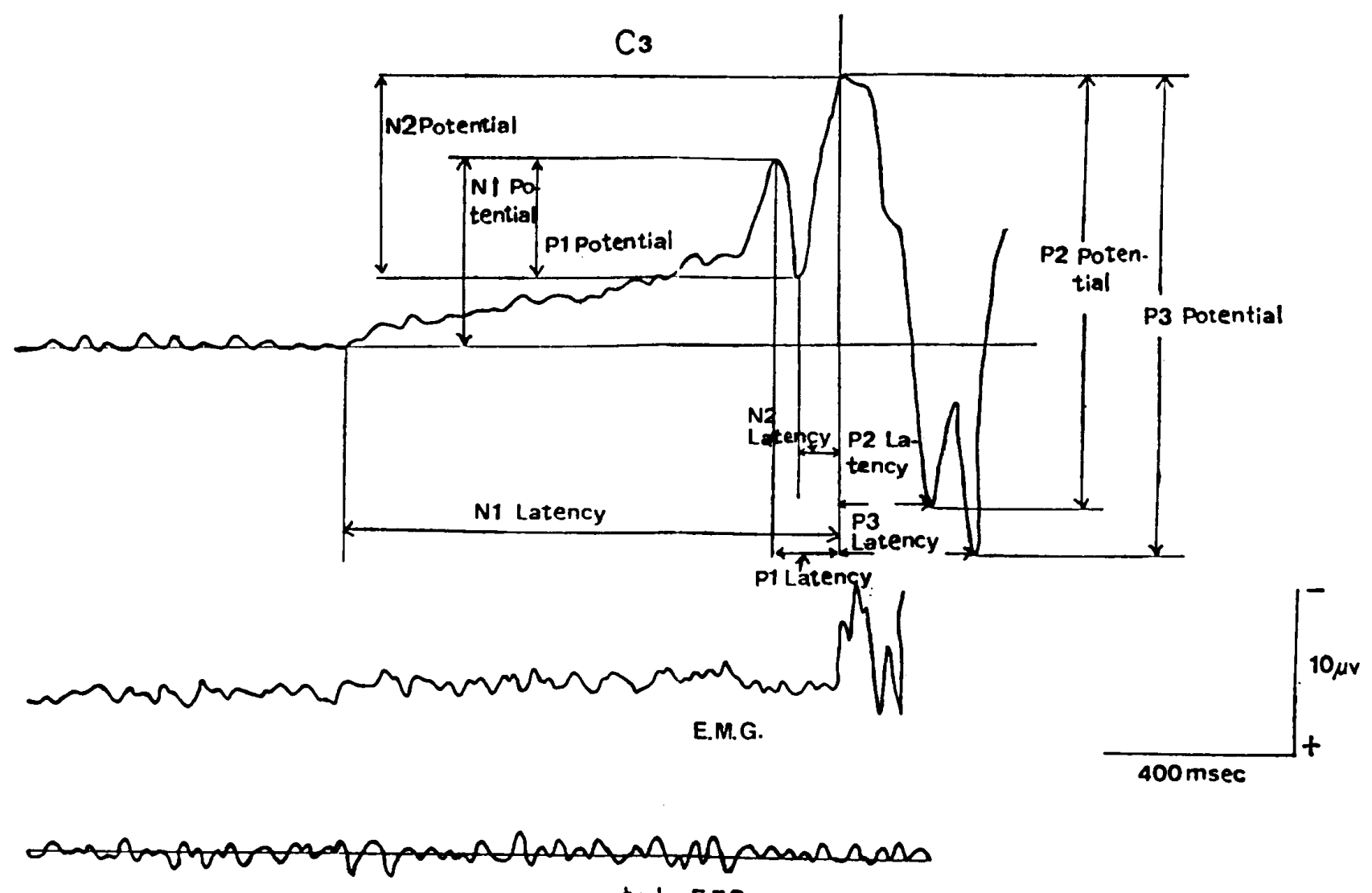

control E.E.G.

Fig. 2 Typical example of movement-associated cortical potential and the measurement criterion. 

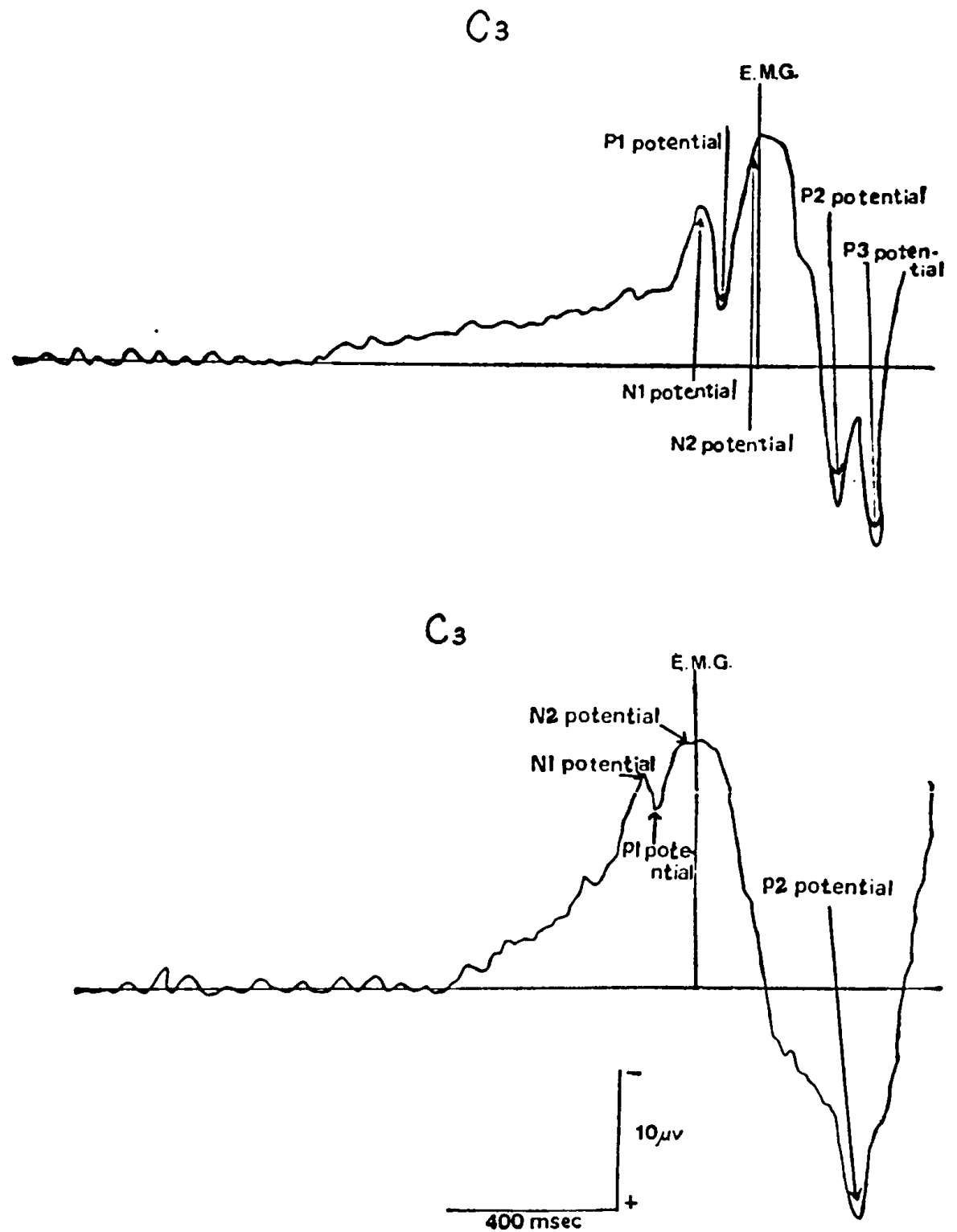

Fig. 3 Definite example of $\mathrm{P}_{2}$ potential and $\mathrm{P}_{3}$ potential appearing after voluntary movement (upper figure). Indefinite example of $\mathrm{P}_{3}$ potential appearing after voluntary movement (lower figure).

\section{実 験 结 果}

A $\mathrm{N}_{1}$ 電位 (準備電位) と $\mathrm{N}_{2}$ 電位（運動電位） の頭皮上分布の相違について

Fig. 6， 7 は，自発的な右上腕屈曲動作，左上 腕屈曲動作遂行の場合の $\mathrm{N}_{1}$ 電位, $\mathrm{N}_{2}$ 電位（運動 電位）の頍皮上分布を示したものである。

Fig. 6, 7 からわかるごとく, $\mathrm{N}_{1}$ 電位の頭皮上 分布は, 自発的な右上腕屈曲動作の場合は，導出 部位 $\mathrm{C} z$ が常に最大の振幅を示し, 次いで $\mathrm{C}_{3}, \mathrm{C}_{4}$ の順であった。

自発的な左上腕届曲動作の場合においても，導
出部位 $\mathrm{C} 2$ は常に最大の振幅を示したが, $\mathrm{C}_{3}$ と $\mathrm{C}_{4}$ を比較すれば， $\mathrm{C}_{4} 、 \mathrm{C}_{3}$ の順であった。これらを 有意差検定してみると次の通りであった。

自発的な右上腕屈曲動作の場合

（各導出部位間の平均振幅の比較）

$$
\begin{array}{llll}
\mathrm{C}_{2}-\mathrm{C}_{3} & \mathrm{P}<0.05 & \mathrm{C}_{3}-\mathrm{C}_{4} & \text { not sig. } \\
\mathrm{C}_{2}-\mathrm{C}_{4} & \mathrm{P}<0.05 & \mathrm{C}_{3}-\mathrm{P}_{3} & \text { not sig. } \\
\mathrm{C}_{2}-\mathrm{P}_{3} & \mathrm{P}<0.05 & \mathrm{C}_{3}-\mathrm{P}_{4} & \text { not sig. } \\
\mathrm{C}_{2}-\mathrm{P}_{4} & \mathrm{P}<0.05 & \mathrm{C}_{4}-\mathrm{P}_{3} & \text { not sig. } \\
& & \mathrm{C}_{4}-\mathrm{P}_{4} & \text { not sig. }
\end{array}
$$

自発的な左上腕届曲動作の場合

（各導出部位間の平均振幅の比較） 


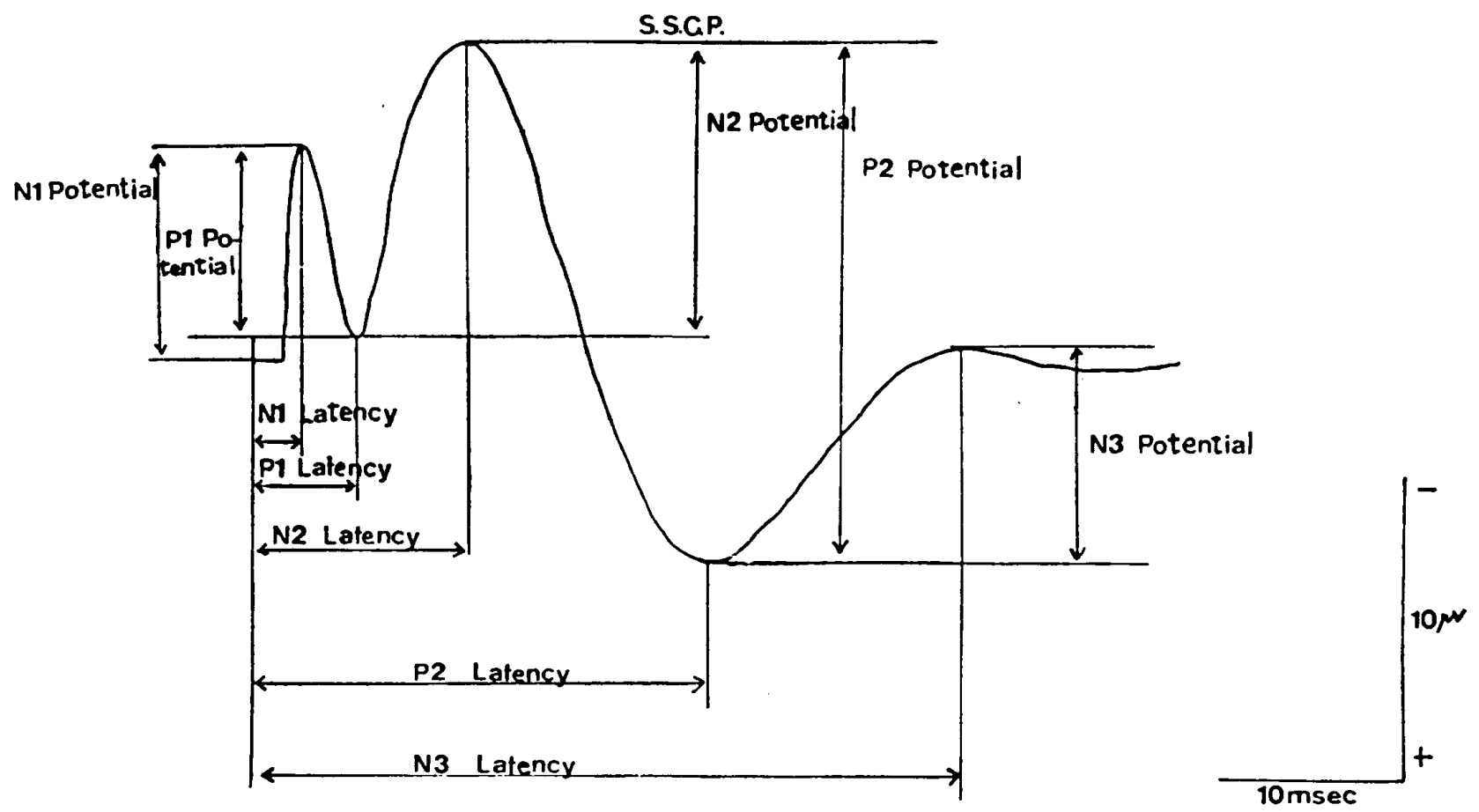

Fig. 4 Typical example of somatosensory, stimulation, cerebral evoked, potential (S.S.C.P) and the measurement criterion.

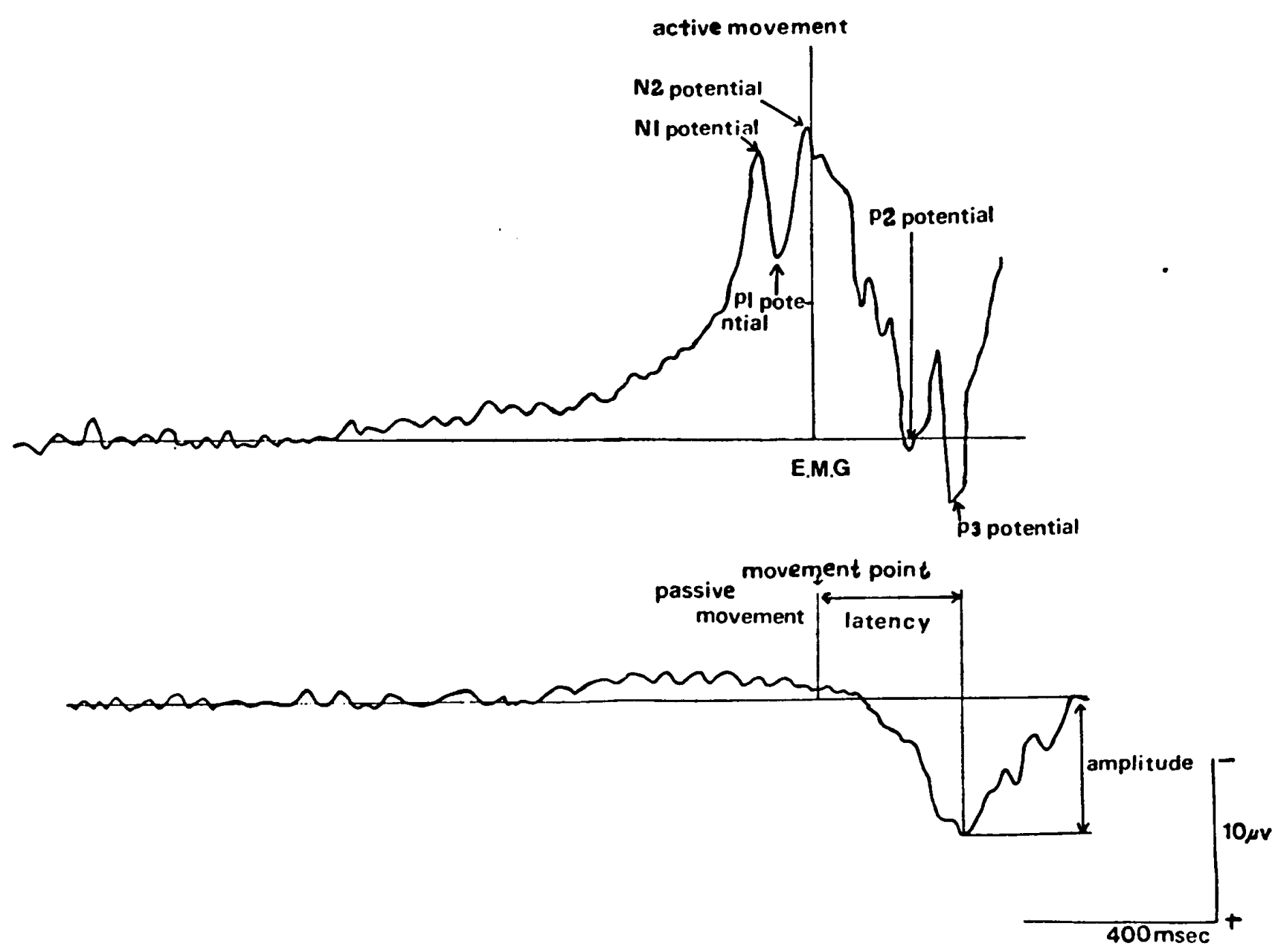

Fig. 5 Movement-associated cortical potential accompanying voluntay movement (upper figure). Positive potential appearing after passive movement (lower figure). 

$\mathrm{C}_{2}-\mathrm{C}_{3} \quad \mathrm{P}<0.05$
$\mathrm{C}_{3}-\mathrm{P}_{3} \quad$ not sig.
$\mathrm{C}_{3}-\mathrm{P}_{1}$ not sig.
$\mathrm{C}_{2}-\mathrm{C}_{4} \quad \mathrm{P}<0.05$
$\mathrm{C}_{3}-\mathrm{C}_{4}$
not sig.
$\mathrm{C}_{2}-\mathrm{P}_{4} \quad \mathrm{P}<0.05$
$\mathrm{C}_{4}-\mathrm{P}_{3}$ not sig.
$\mathrm{C}_{4}-\mathrm{P}_{4}$ not sig.

$\mathrm{N}_{2}$ 電位（運動電位）の頭皮上分布を検討して みるに，自発的な右上㧤屈曲動作の場合は，常に 導出部位 $\mathrm{C}_{3}$ が最大の振幅を示し，次いで $\mathrm{C} 2, \mathrm{C}_{4}$ $\mathrm{P}_{3}, \mathrm{P}_{4}$ の順であり，自発的な左上腕㐿曲動作の 場合は，導出部位 C、が常に最大の振幅を示し， 次いで $\mathrm{C}_{2}, \mathrm{C}_{3}, \mathrm{P}_{3}, \mathrm{P}_{4}$ の順であった。これらを 有意差検定してみると次の通りであった。

自発的な右上腕届曲勤作の場合

（各導出部位間の平均振幅の比較）

$$
\begin{array}{llll}
\mathrm{C}_{3}-\mathrm{C}_{2} & \text { not sig. } & \mathrm{C}_{2}-\mathrm{C}_{4} & \text { not sig. } \\
\mathrm{C}_{3}-\mathrm{C}_{4} & \mathrm{P}<0.05 & \mathrm{C}_{2}-\mathrm{P}_{3} & \mathrm{P}<0.05
\end{array}
$$

$$
\begin{array}{llll}
\mathrm{C}_{3}-\mathrm{P}_{3} & \mathrm{P}<0.05 & \mathrm{C}_{2}-\mathrm{P}_{4} & \mathrm{P}<0.05 \\
\mathrm{C}_{3}-\mathrm{P}_{4} & \mathrm{P}<0.05 & \mathrm{C}_{4}-\mathrm{P}_{3} & \mathrm{P}<0.05 \\
& & \mathrm{C}_{4}-\mathrm{P}_{4} & \mathrm{P}<0.05
\end{array}
$$

自無的な左上腕㐿曲動作の場合

（各導出部位間の平均振幅の比較）

$\begin{array}{llll}\mathrm{C}_{4}-\mathrm{C}_{2} & \text { not sig. } & \mathrm{C}_{4}-\mathrm{P}_{3} & \text { not sig. } \\ \mathrm{C}_{4}-\mathrm{C}_{3} & \mathrm{P}<0.005 & \mathrm{C}_{4}-\mathrm{P}_{4} & \text { not sig. } \\ \mathrm{C}_{2}-\mathrm{C}_{3} & \mathrm{P}<0.05 & \mathrm{C}_{3}-\mathrm{P}_{3} & \text { not sig. } \\ \mathrm{C}_{2}-\mathrm{P}_{3} & \text { not sig. } & \mathrm{C}_{3}-\mathrm{P}_{4} & \text { not sig. } \\ \mathrm{C}_{2}-\mathrm{P}_{4} & \text { not sig } & & \end{array}$

B $\mathrm{P}_{2}$ 電位（運動後第 1 踼性電位）の頭 皮上 分布について

Fig. 8 は， $\mathrm{P}_{2}$ 電位（運動後第 1 陽性電位）の 頭皮上分布を示したものである。Fig. 8 からわか るごとく，自発的な右上胳㐿曲動作の場合導出部 位 $\mathrm{Cz}$ で最大の振幅を示し，次いで $\mathrm{C}_{3}, \mathrm{C}_{4}$ の順 NI potential

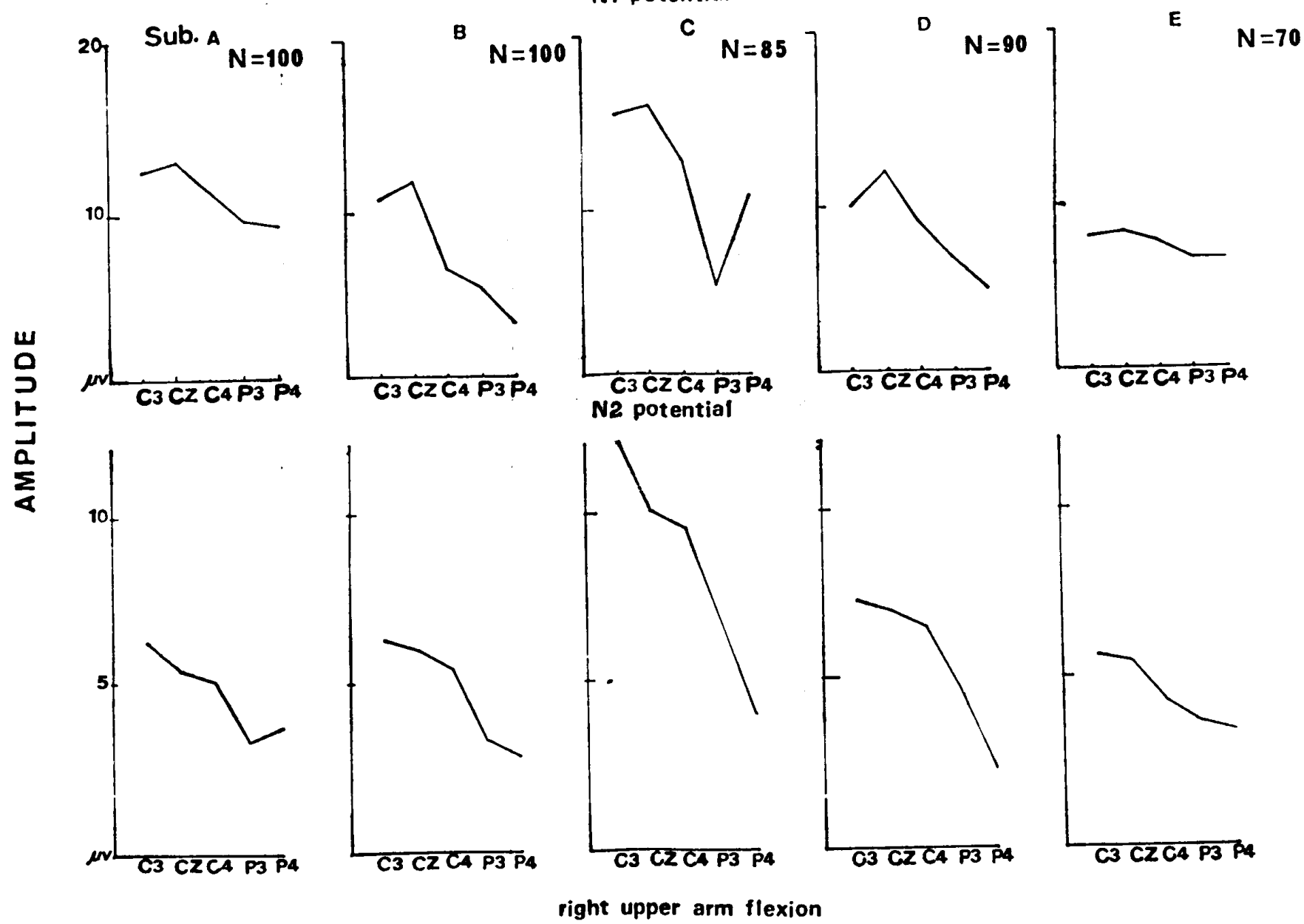

Fig. 6 The distribution over the scalp of $\mathrm{N}_{1}$ potential and $\mathrm{N}_{2}$ potential in case of voluntary right upper arm flexion movement. abscissa : lead placement ordinate : amplitude $N$ (averaging numbers) 
であり，自発的な左上腕届曲的作の場合も，等出 部位 $\mathrm{C}_{2}$ で最大の振幅を示し，次いで $\mathrm{C}_{4}, \mathrm{C}_{3}$ の 順であった。これらの結果は， $\mathrm{N}_{1}$ 電位の頭皮上 分布とほとんど類似している傾向を示しており， 統計的に処理してみても有意差は， $\mathrm{N}_{1}$ 電位の場 合とほとんど同じ傾向を示した。

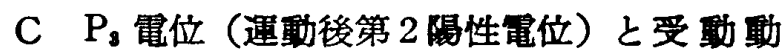
作後に出現する隄性電位の頭皮上分布について

Fig. 9 は, $\mathrm{P}_{3}$ 電位(運動後第 2 陽性電位) と受 動動作後に出現する陽性電位の頭皮上分布を示し てある。Fig 9 からわかるごとく，Ps電位（運 動後第 2 陽性電位）と受動動作後に出現する晹性 電位の振幅を比べてみると， $\mathrm{P}_{3}$ 電位（運動後第 2 陽性電位）の掁幅が著明に高い傾向にあった。 さらに，Ps 電位（運動後第 2 陽性電位）と受㕫 䣦作後に出現する陽性電位の頭皮上分布を検討し てみるに，両電位は，両半球上に両側的に出現
し，電位の振幅柱等出部位 $\mathrm{P}_{\mathbf{a}} ， \mathrm{P}_{4}$ を除くと，著 明な差はみられなかった。

D 脳運動関連電位 $\left(\mathrm{P}_{1}, \mathrm{~N}_{2}, \mathrm{P}_{2}, \mathrm{P}_{3}\right.$ 電位 $)$, 受動動作後に出現する陽性電位（ $\mathrm{P}$ 電位）の出現 潜時について

Fig.10は，脳運踖成連電位の中の $\mathrm{P}_{1}$ 電位（運 動前陽性電位)， $\mathrm{N}_{2}$ 電位（運動電位）， $\mathrm{P}_{2}$ 電位（運

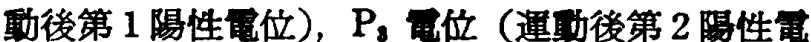
位）之，受跑亚作後陽性電位（ $\mathrm{P}$ 電位）の出現潜 時を示したものである。Fig．10 からわかるごと $く, \mathrm{P}_{1}$ 電位（運動前陽性電位）は随意䡃作に先 行して約178土56msecに出現し， $\mathrm{N}_{2}$ 電位は随意陻 作前䄪139土48mseck出現した。 $\mathrm{P}_{2}$ 電位（運塄後 第 1 陽性電位）は随意看作後約 $160 \pm 24 \mathrm{msec}$ に出 現し， $\mathrm{P}_{3}$ 電位（運動後第 2 陽性電位）は随意動 作後的263土36msec に出現した。受動動作後に出 現する陽性電位 ( $\mathrm{P}$ 電位) は, $\mathrm{P}_{3}$ 電位（運 動 後

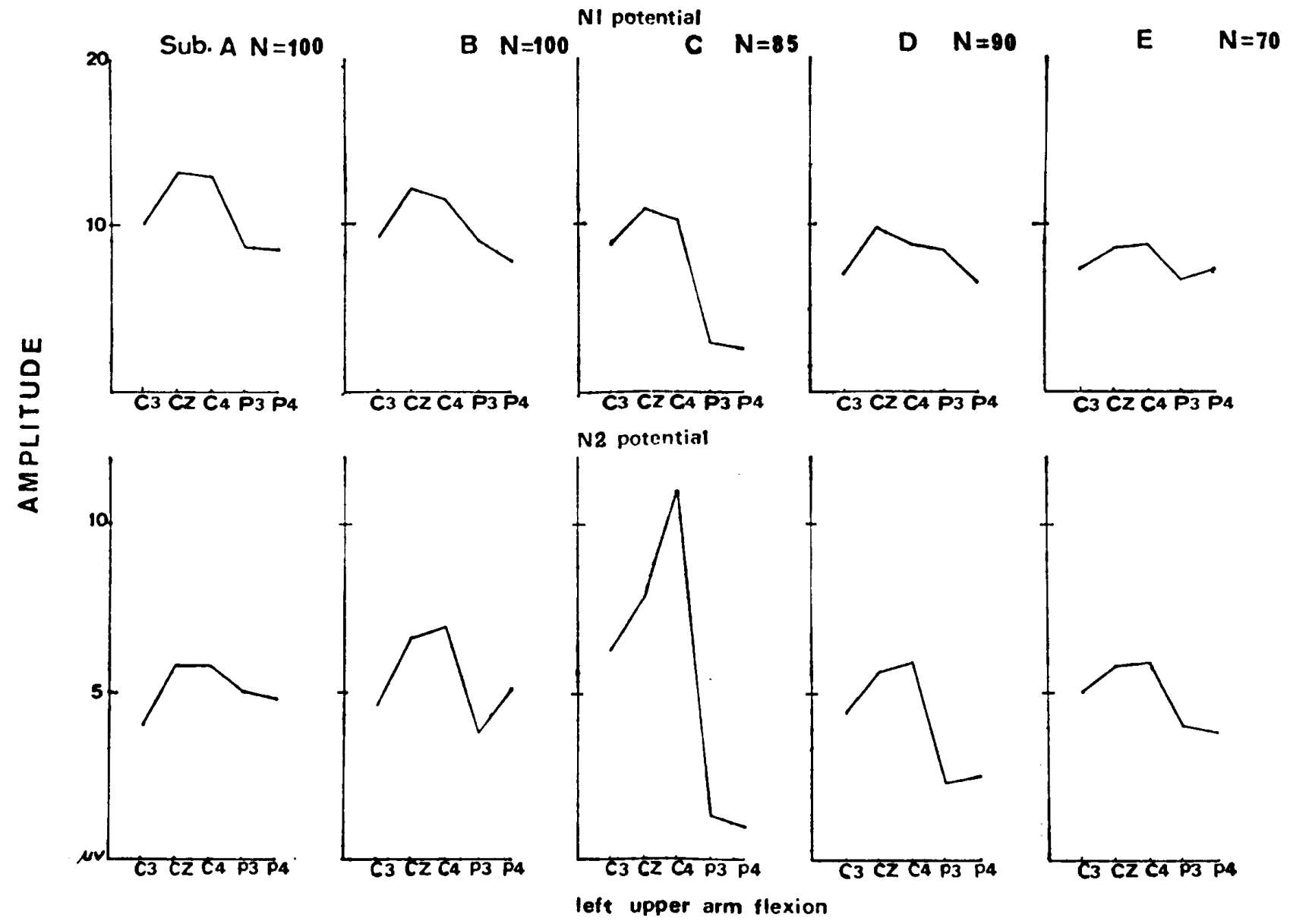

Fig. 7 The distribution over the scalp of $N_{1}$ potential and $N_{2}$ potential in case of voluntary left upper arm flexion movement.

absciassa : lead placement ordinate : amplitude $\mathrm{N}$ (averaging numbers) 


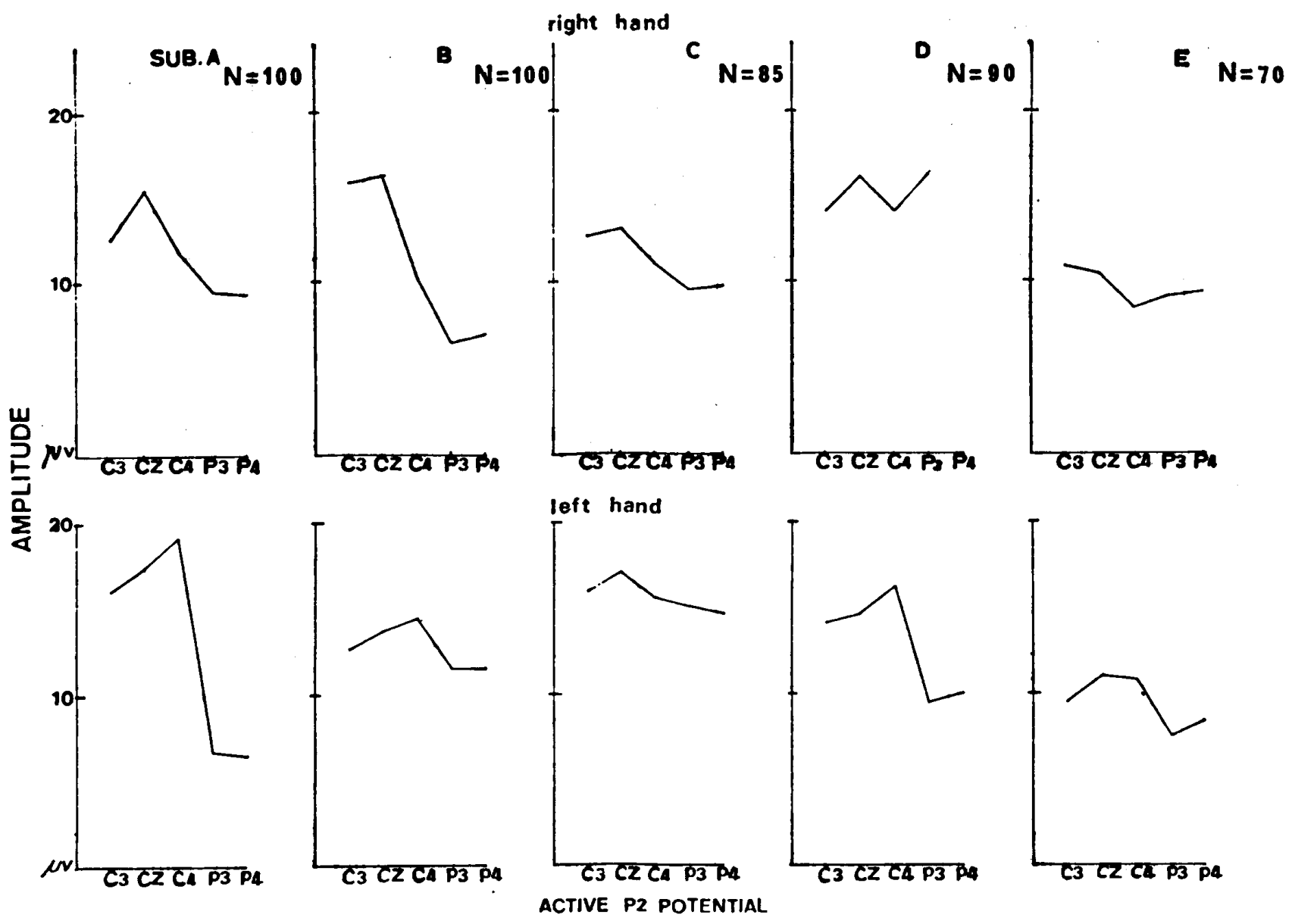

Fig. 8 The distribution over the scalp of $\mathrm{P}_{2}$ potential accompanying voluntary movement. abscissa : lead placement

第 2 陽性電位）よりもわずかに長い傾 向にあっ た。

しかし，たとえ受動動作後に出現する陽性電位 ( $\mathrm{P}$ 電位) が, 随意動作後に出現する $\mathrm{P}_{2}$ 電位（運 動後第 1 陽性電位)， $\mathrm{P}_{3}$ 電位（運動後第 2 陽性電 位）よりも長い傾向にあったとしても，P電位の 潜時は, $\mathrm{P}_{2}$ 電位（運動後第 1 陽性電位）の潜時よ りも $\mathrm{P}_{3}$ 電位（運動後第 2 陽性電位）の潜時にきわ めて近似的であった。

E 体性感覚剌激大脳誘発電位 (S.S.C.P.) 成分 の変化について

Fig. 11 は，S.S.C.P. の頭皮上分布を示したも のである。Fig.11からわかるごとく，右正中神 経刺激の場合, $\mathrm{P}_{1}$ 電位, $\mathrm{N}_{2}$ 電位のいずれも, 刺 激側と反対側半球, 特に前頭葉の中心領野の付近 で優位を示した。しかしながら，左正中神経刺激 の場合はその逆の傾向を示した。
考察

実験目的のところで叙述したごとく，著者らは これまで， $\mathrm{N}_{1}$ 電位の頭皮上分布， $\mathrm{N}_{1}$ 電位と動作 遂行の準嘴状態との関連性について検討24),25) し てきたのであるが，本論文においては，脳運動関 連電位の中の $\mathrm{N}_{2}$ 電位 (運動電位), $\mathrm{P}_{2}$ 電位 (運動 後第 1 陽性電位), $\mathrm{P}_{3}$ 電位（運動後第 2 陽性電位） に考察を限定した。

A $\mathrm{N}_{2}$ 電位 (運動電位) について

Fig.6，7から明らかなように， $\mathrm{N}_{2}$ 電位の頭皮 上分布は， $\mathrm{N}_{1}$ 電位のそれとは明白な相違を示し， 自発的な右上腕届曲動作の場合は，導出部位 $\mathrm{C}_{3}$, 自発的な左上腕屈曲動作の場合は導出部位 $\mathrm{C}_{4}$ の 方が最大の振幅を示している。

さらに， $\mathrm{N}_{2}$ 電位の潜時はFig.10からわかるごと く,筋放電に先行して約139士48mmsecであった。 従って，たとえ L.K. Gerbrandt et al. (1973) 


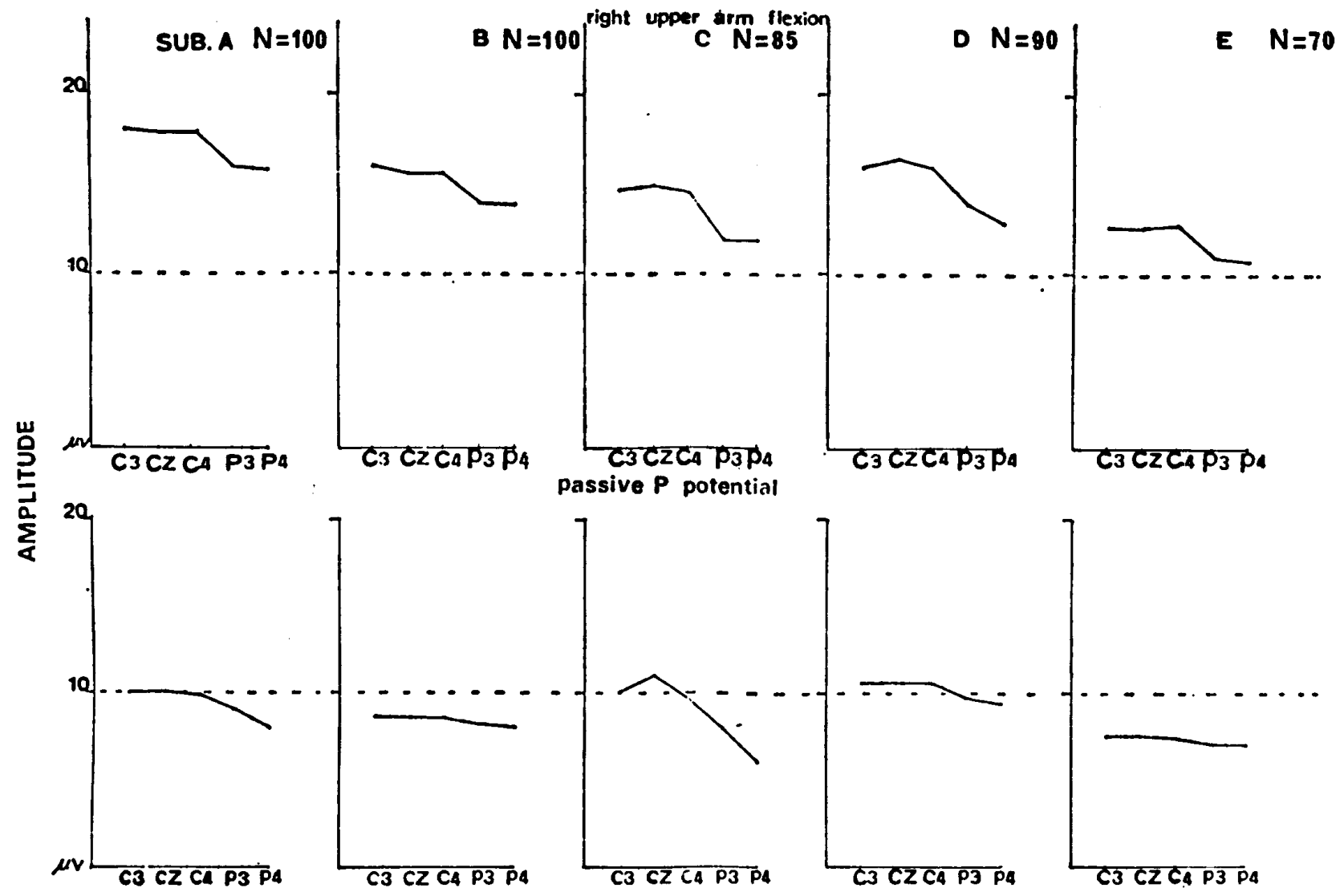

Fig. 9 The distribution over the scalp of $\mathrm{P}_{3}$ potential accompanying voluntary movement and positive potential appearing after passive movement. abscissa : lead placement ordinate : amplitude

$N$ (averaging numbers)

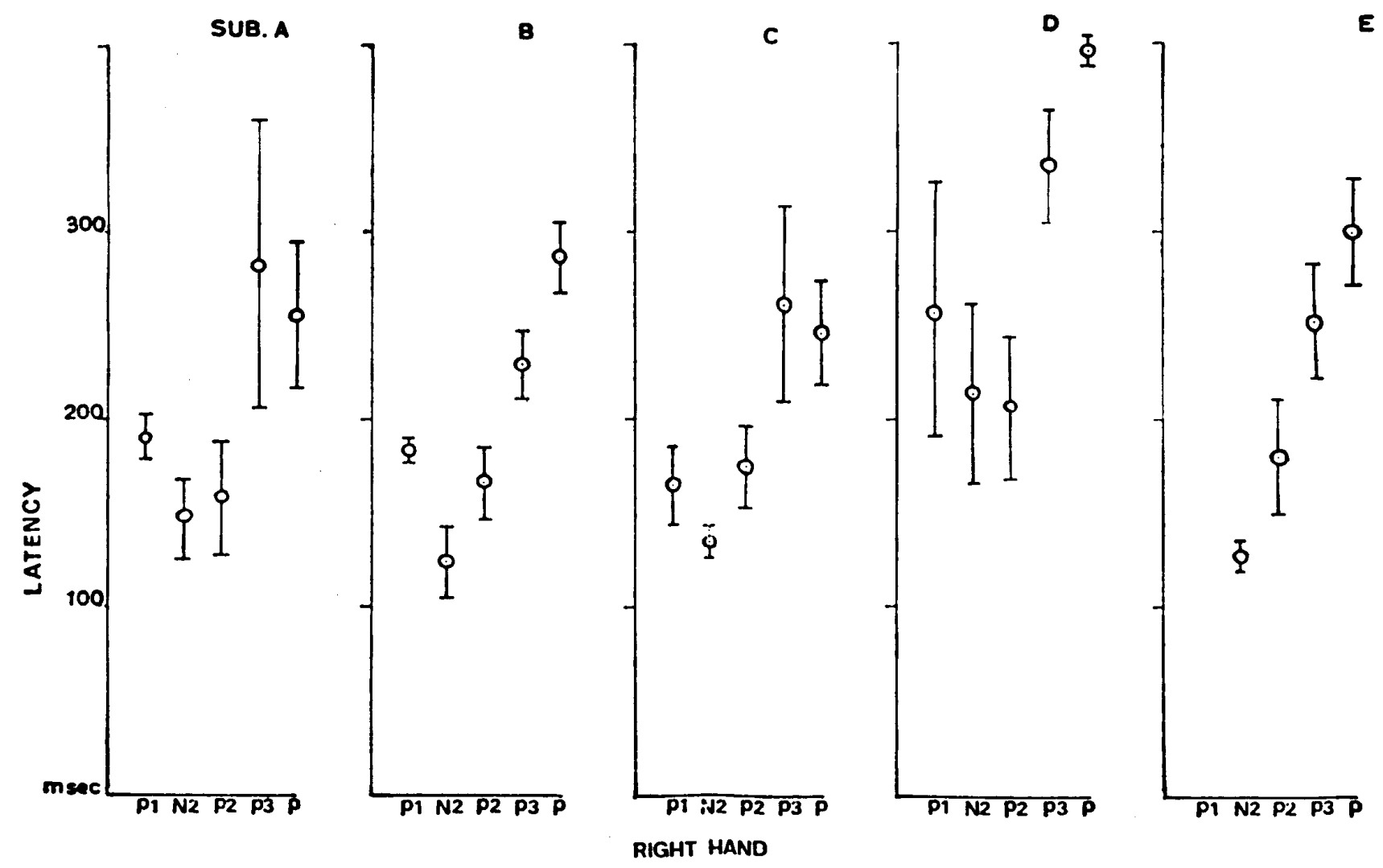

Fis. 10 Appearance latency of movement-associated cortical potentials $\left(P_{1}, N_{2}, P_{2}, P_{3}\right.$ potentials) and positive potential appearing after passive movement. abscissa : cortex potential components ordinate : appearance latency $\mathrm{N}=5$ (showing 5 lead placements. $\mathrm{C}_{3}, \mathrm{Cz}_{2}, \mathrm{C}_{4}, \mathrm{P}_{3}, \mathrm{P}_{4}$ in each subject) 


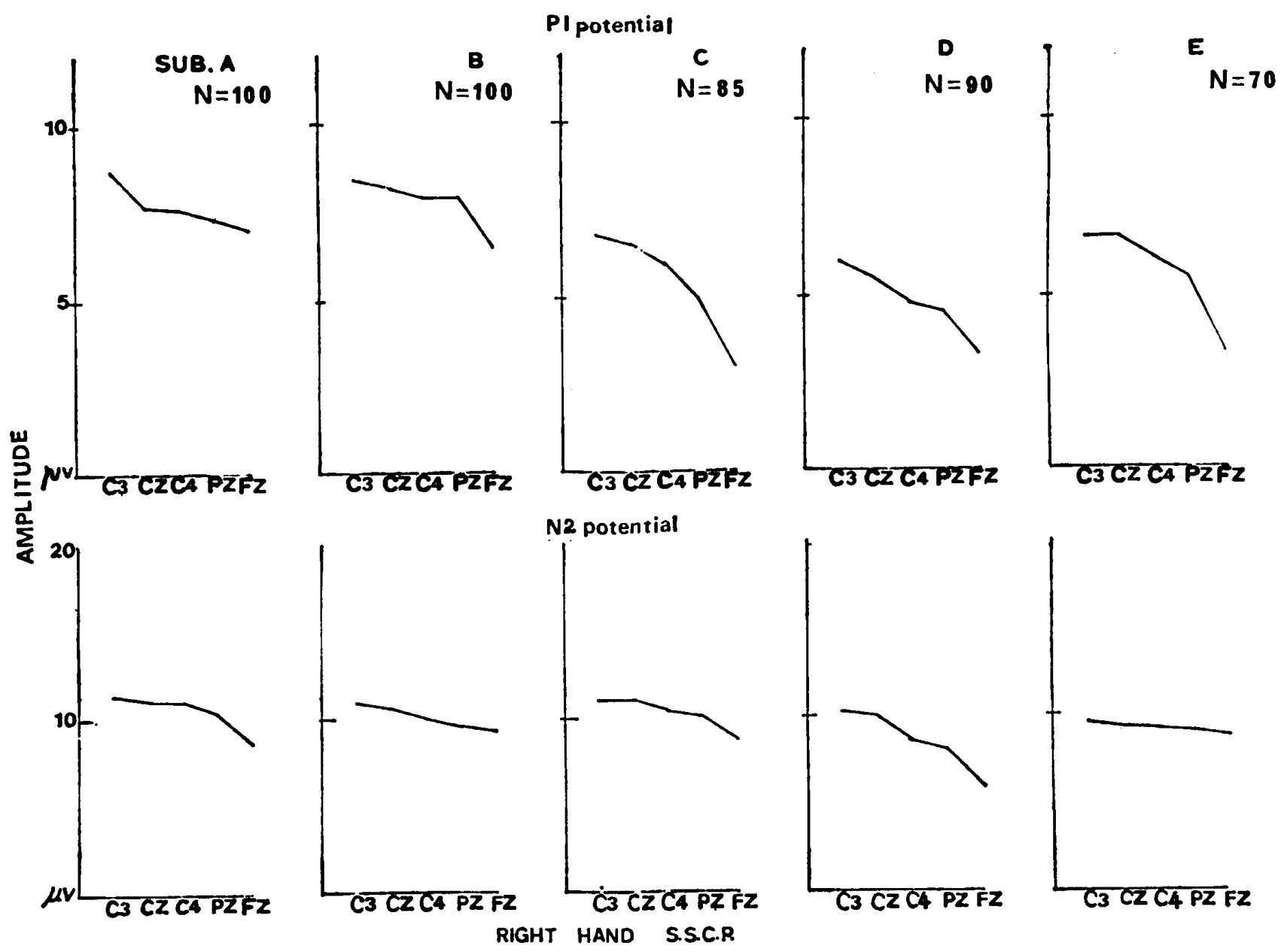

Fig. 11 The distribution over the scalp of $\mathrm{P}_{1}$ potential and $\mathrm{N}_{2}$ potential of somatosensory, stimulation, cerebral evoked, potentials.(S.S.C.P.)

abscissa : lead placement

ordinate : amplitude

$\mathrm{N}$ (averaging numbers)

及び柴崎 $(1974-1977)$ 19),20),21,22),23)らが, $\mathrm{N}_{2}$ 電 位は筋放電後に出現する可能性が強いと報告した としても，本実験においては明白に筋放電に先行 して出現した。H.H. Kornhuber and L. Deeke (1965) ${ }^{11)}$ も以前から， $\mathrm{N}_{2}$ 電位は筋放電に先行して 約 $56 \mathrm{msec}$ に出現することを埌告しているし，青 山ら (1978) 15) も動作に先行して約50msec に頭皮 上から, negative potential が出現することを 報告している。

さらに, J. Arezzo et al. (1977)2)は,サルを 用いての詳細な方法により， $\mathrm{N}_{2}$ 電位は筋放電に 先行して約50-100 mseck出現することを確認し ているばかりでなく，皮質電位と同時に皮質内か 5 multiple unit activity を測定し, multiple unit activity は筋放電に先行して約 80〜90msec に相動的なバーストを示すと報告している。それ
ゆえ，現在においてはN 2 電位は L.K.Gerbrandt et al. (1973) 9)および，柴崎ら(1974-1977)19),20) 21，22，23）の報告とは相反して，筋放電に先行して 出現するという仮説を支持する報告が多くなって いる。これらのことは，E.V. Evarts (19646), 19657)，19748))のサルを用いての一連の研究報告 によっても十分支持することができる。

頭皮上分布に関しても，H.H. Kornhuber and L. Deeke (1965) 11)，青山ら (1978) 15)及び J. Arezzo et al. (1977) 2) は, 本実験結果と同様に, 動作 肢と反対側半球の運動野相当部位上で最大の振幅 を示したと報告している。特に，J. Arezzo et al. (1977) 2) は， $\mathrm{N}_{2}$ 電位は筋放電侁先行して 約50$100 \mathrm{msec}$ 出に現し，対側中心前回において最大の 振幅を示し，さらに中心前領野内では極性が逆転 を示すことから，考察として， $\mathrm{N}_{2}$ 電位は皮質脊 
铕路 out-flow と関連がある皮質活動を反映し ている可能性が強いと報告している。

さらに，J. Arezzo et al. (1977) 2) が， $\mathrm{N}_{1}$ 電 位, $\mathrm{N}_{2}$ 電位, $\mathrm{P}_{1}$ 電位 (運動前陽性 電 位) は, 電 極が大脳皮質の 4 唐， 5 層を横切る時に極性が逆 転を示すことを報告していることから， $\mathrm{N}_{1}$ 電位， $\mathrm{N}_{2}$ 電位, $\mathrm{P}_{1}$ 電位の generation は皮質の深 層部 にあることが推察される。

そこで，本実験 結 果, H.H. Kornhuber の仮 説, E.V. Evarts (19645), 19656), 19737). $\left.1974^{8}\right)$ ) の一連の研究, W.T. Thach (197012). 197813)）改び J. Arezzo et al. (1977)2)の基礎研 究に論拠を置き， $\mathrm{N}_{2}$ 電位について考察してみる と, 筋放電出現との時間的関係, 顽皮上分布から して， $\mathrm{N}_{2}$ 電位は錐体路の這心性放電に関する神 経興奮の表現，すなわち皮質资隦道路活動を反映し ている篂位ではなかろうかと推察される。

L. Deeke et al. (1973) 4) む指摘しているごと く, 随意動作は頭頂，他の連合野あるいは，感覚 運動野に扔いてひき抗こされた後，小脳へは皮質 一橋一小脳径路を経て伝えられる。小脑は，小脳 一視床一皮質径路を経て，運動皮質へ情報を伝え ると考えられている。従って，柴崎 $\left(1974^{20)} .1977\right.$ 21)）も随意動作に先行する脳運動関連電位発現に は小脳皮啠下核の領域が関与していると指摘して いるごとく， $\mathrm{N}_{2}$ 電位の発現には上記の L. Deeke et al. (1973)4)が主張した神経径路が成与してい る可能性が十分にあると考える。

それゆえ， $\mathrm{N}_{2}$ 電位は動作遂行そのものに直接 関与する電位である可能性が推察される。

$B$ 運動後陽性電位 $\left\{\mathrm{P}_{2}\right.$ 電位（運動後第 1 隄 珄 電位), $\mathrm{P}_{3}$ 電位 (運動後第 2 陽性電位) $\mathrm{P}$ 電位 (受 動動作後陽性電位)\}について

Fig. 8 から明らかなように, $\mathrm{P}_{2}$ 電位（運後後 第 1 陽性電位）はN $N_{1}$ 電位の頭皮上分布とほと儿 ど類似していて, 自発的な左, 右上腕届曲動作の いずれの動作においても導出部位 $\mathrm{C} z$ が常に最大 の振幅を示した。ところが，Fig.9 からわかる ごとく, $\mathrm{P}_{8}$ 電位（運動後第 2 陽性電位）, 受動届 曲動作後に出現する $\mathrm{P}$ 電位 (陽性電位) は, 荅出 部位 $\mathrm{P}_{8}, \mathrm{P}_{4}$ を除くと両側的に両半球上に優位を示 した。
これらのことから， $\mathrm{P}_{2}$ 電位（運䟭後第 1 陽性電 位), $\mathrm{P}_{8}$ 電位（運動後第 2 陽性電位）の両菴位は, 両方とも随意動作後に出現した電位であったとし ても，頭皮上分布は明白に異なっている。

さらに出現潜時を比較してみても，Fig．10 か らわかるごとく， $\mathrm{P}_{2}$ 電位（運動後第 1 陽性電位） は随意動作後約 $160 \pm 24 \mathrm{msec}$ に, $\mathrm{P}_{3}$ 電位（運動後 第 2 陽性電位）は約 $263 \pm 36 \mathrm{msec}$ に出現し，出現 潜時においても明白な相違を示している。本実験 結果によれば， $\mathrm{P}_{3}$ 電位（運動後第 2 陽性電位）は むしろ頭皮上分布に拉いては，受動屈曲動作後の $\mathrm{P}$ 電位ときわめて類似しているように思われる。 さらに，出現潜時においても $\mathrm{P}$ 電位の方が長い傾 向にあるが，しかし，他の電位成分よりは $\mathrm{P}_{3}$ 電位 （運動後第 2 陽性電位）ときわめて近い值を示し ている。正中神経を経皮的に電気刺激して頭皮上 から誘発された S.S.C.P. は，黒岩と加藤 (1968) 16)及び G.D. Goff et al. (1977) ${ }^{10)}$ の報告したと おり，剌激側と反対側の半球上で優位を示した が，全頭皮上から判断すれば運動野相当部位上で 優位を示し, 被検者によっては両側的に両半球上 に出現する場合もあった。

これらの結果から, S.S.C.P. の頭皮上分布は $\mathrm{P}_{8}$ 電位（運動後第 2 陽性電位）のそれと極めて類 似しているように思われる。徒って, 以上のこと から，たとえ $\mathrm{P}_{2}$ 電位 (運動後第 1 陽性 電位), $\mathrm{P}_{3}$ 電位（運憡後第 2 陽性電位）が随意動作後に出現 する陽性電位であったとしても，出現潜時，頭皮 上分布などの相違からして, 両電位の出現機構は 多少異なっている可能性が十分推晸できる。

H.G. Vaughan and E.G. Gross (1970)14) の サルを用いての実験によれば，求心性線維を遮断 しても，随意動作が可能であり，加えて随意動作 後には陽性電位が出現することを埌告している。 さらに, 脱求心性線維を行なってむ脳電位の出現 潜時は若干遅延こそ示すけれどす，随意動作に伴 って頭皮上から出現する 4 つの電位成分は完全に 出現するということである。

H.G. Vaughan and E.G. Gross (1970) ${ }^{14)}$ が報 告している脳電位の中で，随意動作後に出現する 隄性電位は，出現潜時，頭皮上分布などからし て, 著者らが本論文で取り扱っている $\mathrm{P}_{2}$ 電位（運 
動後第 1 陽性電位）とほとんど同じ電位であると 考えてもまちがいあるまい。従って，これらのこ とから， $\mathrm{P}_{2}$ 電位（運動後第 1 陽性電位）を求心性 の末梢 feed-back の反映したものであると考え ることはむはや不可能であろう。

J. Arezzo et al. (1977)2) 2 む，サルを用いての 詳細な研究から， $\mathrm{P}_{2}$ 電位（運動後第 1 陽性電位） は中枢中 feed-back の反映であると仮定してい る。その理由として，J. Arezzo et al. は次のよ うなことを論观にあげている。(1) 脱求心性線維 のサルにおいても $\mathrm{P}_{2}$ 電位に相当する陽性電位は出 現する。(2) 末梢求心性線維は $\mathrm{P}_{2}$ 電位の発現に関 与するであろう領域まで広がっておらず，体性感 覚刺激大脪話発電位の配分は中心溝の前方に限局 している。

これらのことからも， $\mathrm{P}_{2}$ 電位が求心性の末梢 feed-back の反映したものであると考元ることは 不可能であろう。しかしながら， $\mathrm{P}_{2}$ 電位を J. Arezzo et al. が主張するように, 中权内 feedback の反映と考えたとしても， $\mathrm{P}_{2}$ 電位を発現さ せる中枢部位はどこか, もう少し詳細な実験的検 討が必要であろうと思われる。

H.G. Vaughan and E.G. Gross $(1970)^{14) の}$ 報告においては，眖求心性線維のサルでは， $\mathrm{P}_{2}$ 電 位に相当する陽性電位は観察されたが， $\mathrm{P}_{3}$ 電位(運 動第 2 陽性電位）に相当する電位は観察されてい ない。また，J. Arezzo et al.は随意動作後約 $265 \mathrm{msec}$ に陽性の電位変化を確認し，その電位は 両側的に両半球上に優位に出現していることを報 告1,)2)している。さらに，酒田 (197217), 1976 18)) もサルを用いて体性感覚入力を多く受け入れてい る領野 5 で $\mathrm{P}_{3}$ 電位に相当する電位を確認してい る。J. Arezzo et al. (1977)2)の報告によれば, 体性感覚入力は領野 5 内で unit 活動を誘発し, $\mathrm{P}_{3}$ 電位に相当する電位を出現させると報告してい る。従って，本実験結果, 酒田 $\left(1972^{17)}, 1976^{18)}\right)$ J. Arezzo et al. (1977)2) 及び H.G. Vaughan and E.G. Gross（1970）14)などの報告を論拠にし て $\mathrm{P}_{3}$ 電位について考察してみると, $\mathrm{P}_{3}$ 電位こそ体 肢位の情報をシグナル化している末梢 feed-back を反映した電位ではないかと推察される。

しかし，たとえ上述のことから， $\mathrm{P}_{3}$ 電位と受動
届曲㲜作後に出現するP電位が末梢 feed-backを 反映した電位であると考えられたとしても，耐電 位の振幅を比㜞してみると， $\mathrm{P}_{3}$ 電位の方が著明 に高い傾向にあった。

これらのことは，たとえ上述の両電位が末梢 feed-back によってひきおこされた電位であった としても，主に皮質脊餚路 out-flow が関与して いると考えられる随意的な動作の場合と受動的な 動作の場合とでは，振幅，出現潜時において明白 な相違が存在するということを示している。

\section{引用・参考文献}

1) Arezzo ,J. and Vaughan, H.G., "Cortical potential associated with voluntary movements in the monkey," Brain Research, 88 : 99-104, 1975.

2) Arezzo, J., Vaughan, H.G., and Koss, B., "Relationship of neuronal activity to gross movement-related potentials in monkey pre-and postcentral cortex," Brain Research, 132 : 362-69, 1977.

3) Deeke, L., Scheid P., and Kornhuber, H.H., "Distribution of readiness potential, pre-motion potential, and motor potential of the human cerebral cortex preceding voluntary finger movement", Exp. Brain Res., 7 : 158-68, 1969.

4) Deeke, L., Becker, W., Grozinger, B., Scheid, P., and Kornhuber, H.H., "Human brain potentials preceding voluntary limb movement", Electroencephal. Clini. Neurophyiol. Suppl., 33 : 201-04, 1973.

5) Evarts, E.V., "Pyramidal tract activity associated with a conditioned hand movement in the monkey", J. Neurophyiol., $29: 1011-27,1966$.

6) Evarts, E.V. "Temporal pattern of discharge of pyramidal tract neurons during sleep and waking in the monkey", J. Neurophysiol., $27: 152-71$, 1964.

7 ) Evarts, E.V., "Relation of discharge frequence to conduction velocity in pyramidal tract neurons", J. Neurophysiol., $28: 216-28,1965$.

8) Evarts, E.V., "Precentral and postcentral cortical activity associated with visually triggered movement," J. Neurophysiol., $37: 373-81,1974$.

9) Gerbrandt, L.K., Goff, W.R., and Smith, D.B., "Distribution of the human average movement 
potential", Electroencephal. Clini. Neurorophysiol., $34: 461-74,1973$.

10) Goff, G.D., Matsumiya, Y., Allison, T., and Goff, W.R., "The topograph of human somatosensory and auditory evoked potentials," Electroencephal. Clini. Neurophysiol., 42:57-76, 1977.

11) Kornhuber, H.H., and Deeke, L., "Hirnpotentialänderungen des Menschen; Bereitschaftpotentiale und reafferente Potentiale", Pflügers. Arch. Gesphysiol., $284: 1-17,1965$.

12) Thach, W.T., "Discharge of cerebellar neurons related to two maintained postures and two prompt movement : II Purkinje cell output and input." J. Neurophysiol., $33: 537-47,1970$.

13) Thach, W.T., "Correlation of neural discharge with pattern and force of muscular activity, joint position, direction of intended next movement in motor cortex and cerebellum", J. Neurophysiol., $41: 654-76,1978$.

14) Vaughan, H.G. and Gross, E.G., "Cortical motor potential in monkey before and after upper limb deafferentation." Experimental Neurology, 26 : 253 $-62,1970$

15）青山一夫・有坂みさ子・本間徾男・佐藤謙助「随意 動作における反応時間, 光誘発反応および運動電位の 関俰について」禹床檤波，19-9：588-96, 1977.
16）黒岩義五郎・加藤元博「大脳誘発電位とその蕗床的 纫用」神経進歩，12-2：137-47，1968.

17）酒田英夫，「頭項連合野の機能」，伊藤正男 - 島津造 (程), 現代の神経科学(3), 高次这機能と中枢プログ ラミング，産業図畫，1976. pp 145-69.

18）酒田英夫「サルの体性感覚系を研究する立場から」 脳波と筋電国，1：86-88，1972.

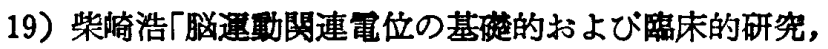

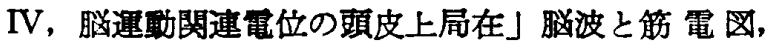
$4-4: 157-64,1976$.

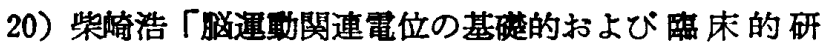
究，V.正常知見の粉括と各種運動障害例における 梌 璟」神経進步, 21-4:743-52, 1977 .

21）柴崎浩 - 加萧元博「脳運動関連電位の基礎的およ び臨床的研究— 1 㑡手運娌に伴う媨连動関連電位の 各成分の㭘討一」」臨床神経, $14: 844-49,1974$.

22）柴崎浩「腷運䙲関連電位，記録法ならびにその意義 に関する知見の総括」堛床脑波，17-5:275-85, 1975.

23）柴崎浩・山下順章・伊完栄「Myoclonus の腅波学 的研究」最新医学, 33-2:236-47, 1977.

24）西平賀昭・藤田紀盛・荒木秀夫「随意野作に先行す る訤運動関連電位」体力科学, 27-4:140-48,1978.

25）西平賀昭・売木秀夫・藤田紀盛「随意野作に先行す

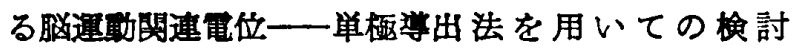
一」体育の科学, 29-10:733-38, 1979. 